\author{
W I T C H C R A F T, A N T I - W I T C H C R A F T A N D \\ TRANS-REGIONAL RITUAL IN NOVATION I N \\ EARLY COLONIAL GHANA: SAKRABUNDI A N \\ A B E R E W A, 1889-1910
}

JOHN PARKER

School of Oriental and African Studies, University of London

\begin{abstract}
This article examines the origins and dynamics of Aberewa, an antiwitchcraft movement that rose to prominence in the Akan forest region of Asante and the Gold Coast (Ghana) in r 906-ıo. It suggests that while the political, social and economic changes of the early colonial period acted as a catalyst for its widespread expansion, Aberewa emerged from an earlier cult called Sakrabundi that was already moving from the savanna into the northern reaches of the Asante empire by the i 880 os. The ritual trajectory and popular appeal of Sakrabundi and Aberewa are explored within the context of the ambivalent relationship between the Akan peoples and their northern savanna neighbours. An argument is made for the need to consider witchcraft and anti-witchcraft in Africa as historical processes rather than as a set of structural beliefs and practices.
\end{abstract}

KEY words: Ghana, Côte d'Ivoire, religion, witchcraft.

I $\mathrm{N}$ the first half of the twentieth century, a succession of religious movements devoted to the eradication of witchcraft swept through the southern forest region of the British colony of the Gold Coast (now Ghana). ${ }^{1}$ The earliest was animated by a deity called Aberewa or, in the Twi language of the Akan peoples, 'The Old Woman'. Aberewa rose to prominence in the Asante heartland in 1906, five years after the annexation of the great Akan forest kingdom by the British, and from there spread south to the older colonial territory of the Gold Coast. For two or three years it attracted large numbers of adherents, but in 1908 was suppressed by the colonial administration and went into rapid decline. Aberewa was followed by Hwemeso ('Watch Over Me'), which enjoyed a similarly widespread but short-lived efflorescence from I 920 to I 923 before it too was outlawed. Hwemeso in turn was succeeded by wave after wave of movements throughout the remainder of the inter-war period. The most prominent were Kunde, Senyakupo, Nana Tongo and Tigare, although many others enjoyed either brief or geographically circumscribed popularity before fading from public view. As a whole, the phenomenon declined after the Second World War, as the healing

1 This article arises from a larger research project conducted in collaboration with Jean Allman of the Center for African Studies at the University of Illinois, ChampaignUrbana, on trans-regional religious change in twentieth-century Ghana focused on the Tongnaab/Nana Tongo ritual network: see Jean Allman and John Parker, Tongnaab: The History of an African God (forthcoming). Thanks to the British Academy for generous financial assistance, to Sonia Abun-Nasr for assistance with material from the Basel Mission Archive and to the readers for their suggestions for revision. 
and protective powers of African gods began to be replaced by those offered by burgeoning numbers of prophetic Christian churches. Yet at least one indigenous 'witch-finder', Tigare, continued to attract a widespread following during the terminal phase of colonial rule. By the early i95os, it appears to have subsumed a number of earlier cults and had spread westwards along the coast into Côte d'Ivoire and eastwards as far as the Yoruba region of Nigeria. As late as I954, moreover, a ritual performance of the Hauka possession cult on the outskirts of Accra was captured on camera by the ethnographer-filmmaker Jean Rouch and released the following yearjust two years before Ghanaian independence - as the controversial film, Les Maîtres Fous.

This narrative is well enough known in outline. As elsewhere on the continent, the apparent proliferation of anti-witchcraft movements in the Gold Coast attracted considerable commentary from government officials, colonial ethnographers and alarmed churchmen. Much of the early literature on the phenomenon was concerned to demonstrate that the cults were recent innovations - that is, were specifically twentieth-century responses to the mounting anxieties brought about by colonial conquest and rapid social change. $^{2}$ One countervailing voice was that of the anthropologist Jack Goody, who disputed the general assumption that the transformations wrought by colonialism had led to a perceived increase in the practice of witchcraft ('Twi: bayi). Questioning the notion of colonial anomie, Goody speculated that twentieth-century witchcraft eradication movements in Asante were more likely to have been the continuation of an older, precolonial tradition - although he was able to offer little in the way of historical evidence to support this thesis. ${ }^{3}$ One crucial aspect of the anti-witchcraft deities upon which all contemporary observers did agree, however, was that they were exotic imports, mostly originating in the savanna country of the Northern Territories Protectorate of the Gold Coast to the north of the Akan forest. ${ }^{4}$ The accepted reason for this was the widely reported perception on the part of the Akan that savanna peoples were free from the worst ravages of

2 The published literature includes M. J. Field, 'Some new shrines of the Gold Coast and their significance', Africa, I3 (1940), I38-49; idem, Akim-Kotoku: An Oman of the Gold Coast (London, 1948), I71-97; idem, Search for Security: An Ethno-Psychiatric Study of Rural Ghana (London, I960); Barbara C. Ward, 'Some observations on religious cults in Ashanti', Africa, 26 (1956), 47-6r ; Rev. H. Debrunner, Witchcraft in Ghana: A Study of the Belief in Destructive Witches and its Effect on the Akan Tribes (Accra, I959); P. Morton-Williams, 'The Atinga cult among the south-western Yoruba: a sociological analysis of a witch-finding movement', Bulletin de l'Institut français d'Afrique noire, I 8 (I956), 3 I5-34. For a useful overview of the literature on Asante, see Malcolm McLeod, 'On the spread of anti-witchcraft cults in modern Asante', in Jack Goody (ed.), Changing Social Structure in Ghana: Essays in the Comparative Sociology of a New State and an Old Tradition (London, I975), 107-17; and more generally, R. G. Willis, 'Instant millennium: the sociology of African witch-cleansing cults', in Mary Douglas (ed.), Witchcraft Confessions and Accusations (London, i 970), I 29-39.

3 Jack Goody, 'Anomie in Ashanti?', Africa, 27 (1957), 356-63. On the limited explanatory value of anomie as a motive for religious innovation, see too the classic study by J. D. Y. Peel, Aladura: A Religious Movement among the Yoruba (London, I 968), esp. 6.

4 The one major exception to this pattern was Hwemeso, which originated on the southwestern frontier of the Gold Coast in Nzima - a region whose inhabitants were renowned amongst the Akan for their intimacy with the supernatural realm. 
maleficent witchcraft. When combined with the advent of colonial peace and an increase in physical mobility, this perception resulted in the development of a thriving cross-cultural trade in ritual commodities.

These insights by contemporary observers have been drawn on to varying extents by later generations of scholars. Yet the latter have tended either to construct general models of ritual change or to use selective data in order to sketch an impressionistic historical backdrop to contemporary ethnographic analysis. ${ }^{5}$ There have been few attempts to reconstruct the dynamics of witchcraft and anti-witchcraft in Ghana as specifically historical phenomena. This neglect of the past is somewhat surprising on two counts. First, the successive waves of witch-finding are voluminously documented in the colonial archive. Second, there has been an extraordinary explosion of anthropological literature over the past decade focused on the 'modernity' of witchcraft, spirit possession and other forms of ritual practice in postcolonial Africa. ${ }^{6}$ The most important exception is T. C. McCaskie's exploratory I 98 I essay on the history of organized anti-witchcraft in Asante from the late I 870 s to the early i 920 s. $^{7}$ This is especially notable for its careful reconstruction from a range of fugitive sources of the only recorded precolonial movement, Domankama, that emerged in i 879-80 before being violently

5 See Richard P. Werbner, Ritual Passage Sacred Fourney: The Process and Organization of Religious Movement (Washington, I989), ch. 6: 'Totemism in history: the sacred crossing of West African strangers'; Fritz Kramer, The Red Fez: Art and Spirit Possession in Africa, trans. Malcolm Green (London, I993), ch. I: 'The Asante and the people from the grasslands'; Paul Stoller, Colonial Memories : Spirit Possession, Power and the Hauka in West Africa (New York, I 995); Judy Rosenthal, Possession, Ecstasy, and Law in Ewe Voodoo (Charlottesville, I998); Jane Parish, 'The dynamics of witchcraft and indigenous shrines among the Akan', Africa, 69 ( 1999), 426-47.

6 From a large and rapidly expanding literature, see the influential collection of essays in Jean Comaroff and John Comaroff (eds.), Modernity and its Malcontents : Ritual and Power in Postcolonial Africa (Chicago, I 993); also African Studies Review, 4 I (Dec. I 998), special issue on 'Containing witchcraft: conflicting scenarios in postcolonial Africa'; George Clement Bond and Diane M. Ciekawy (eds.), Witchcraft Dialogues: Anthropological and Philosophical Exchanges (Athens OH, 200I). Peter Geschiere's research on Cameroon has been crucial: see esp. The Modernity of Witchcraft: Politics and the Occult in Postcolonial Africa (Charlottesville, i 997).

7 T. C. McCaskie, 'Anti-witchcraft cults in Asante: an essay in the social history of an African people', History in Africa, 8 (I98I), I25-54; see too the recent articles by Natasha Gray, 'Witches, oracles, and colonial law: evolving anti-witchcraft practices in Ghana, r927-r 932', International Fournal of African Historical Studies, 34 (2001), 339-63; and William C. Olsen, "“Children for death”: money, wealth, and witchcraft suspicion in colonial Asante', Cahiers d'Etudes Africaines, I67 (2002), 521-50. Elsewhere in Africa, historians have also been slow in reconstructing change and continuity in 'occult' practices over time. An important exception, and still the best historical analysis of antiwitchcraft movements in colonial Africa, is Karen E. Fields's insightful study of the phenomenon in Malawi and Zambia, Revival and Rebellion in Colonial Central Africa (Princeton, I 985); see too the influential statement by Willy de Craemer, Jan Vansina and Renée C. Fox, 'Religious movements in Central Africa: a theoretical study', Comparative Studies in Society and History, I 8 (1976), 458-75. For recent contributions, see Peter Delius, 'Witches and missionaries in nineteenth century Transvaal', Fournal of Southern African Studies, 27 (2001), 429-43; Stephen Ellis, 'Witch-hunting in central Madagascar I 828-г 86I', Past and Present, I75 (2002), 90-г 23; Misty L. Bastian, "“The daughter she will eat agousie in the world of the spirits": witchcraft confessions in missionised Onitsha, Nigeria', Africa, 72 (2002), 84-I I I. 
suppressed by the government of Asantehene Mensa Bonsu. The appearance of Domankama some two decades before Asante came under British rule lends some support to the emphasis on continuity from the precolonial to the colonial period suggested by Goody. But there are also indications that Domankama represented something quite new in Akan approaches to the problem of bayi: a shift from the state-controlled capital punishment of those identified as 'witches' (abayifos, sing. sbayifo) towards popular cultic movements aimed at healing, protection and eradication. ${ }^{8}$

This article seeks to re-engage with these debates by examining the first episode of organized witch-finding in the colonial Gold Coast, Aberewa or 'The Old Woman'. It is structured in two main parts. The first considers the origins of the movement and its gestation in the kingdom of Gyaman on the contested northwestern borderlands of the Asante empire. It demonstrates that Aberewa emerged directly from an earlier cult called Sakrabundi (variously Sakarabouri, Sakarabrou, Sakara-Bounou) that by the i 88 os was already spreading from the savanna south into the Akan forest via the cultural crossroads of Gyaman. The second part analyses the dynamics of witch-finding during the three-year period that 'The Old Woman' dominated the religious landscape of Asante and the Gold Coast Colony. A concern with the shifting forms of anti-witchcraft over time - in particular, over the watershed of colonial conquest-therefore intersects with a second theme: the movement of indigenous gods and other categories of sacred power across space. The latter has been neglected in the extensive and sophisticated historical literature on Asante and the other Akan forest kingdoms. ${ }^{9}$ Cultural dialogue across the forest-savanna divide was one of the first themes to emerge in that literature, but it has focused almost entirely on the role of Muslims and of Islam in precolonial Asante. ${ }^{\mathbf{1 0}}$ The role of the noncentralized savanna peoples in Akan history has been seen to have been limited to the provision of manpower, first as slaves and then, in the twentieth century, as migrant wage labourers. In order to comprehend the

${ }^{8}$ In common with witchcraft belief in much of West and Central Africa, bayi was perceived by the Akan peoples as a destructive force projected either consciously or unconsciously from the mind of the sbayifo that would consume the inner essence or 'soul' of the victim, ultimately leading to the latter's death. In normative terms it was regarded as distinct from the magical manipulation of physical 'poison' (aduto or aduru bone) or evil charms (ogbaniba suman), although in reality these actions were often subsumed under the concept of bayi. The etymology is unclear, but a possible derivation is $s b a$ (child) $+y i$ (to remove), the literal notion 'to take away a child' underscoring the close association of witchcraft with issues of fertility, reproduction and infant mortality: T. C. McCaskie, State and Society in Pre-colonial Asante (Cambridge, I 995), 274; see also the citations in n. 2, and for a fuller treatment, Allman and Parker, Tongnaab.

9 The one important exception remains Donna J. E. Maier, Priests and Power: The Case of the Dente Shrine in Nineteenth-Century Ghana (Bloomington, I983).

10 See, selectively, Ivor Wilks, The Northern Factor in Ashanti History (Legon, I96 I); idem, Asante in the Nineteenth Century: The Structure and Evolution of a Political Order (Cambridge, I975), esp. ch. 7; idem, 'The Juula and the expansion of Islam into the forest', in Nehemia Levtzion and Randall L. Pouwels (eds.), The History of Islam in Africa (Athens OH, 2000), 93-I I 5; Kwame Arhin, 'Savanna contributions to the Asante political economy', in Enid Schildkrout (ed.), The Golden Stool: Studies of the Asante Centre and Periphery (New York, I987), 5I-9; David Owusu-Ansah, Islamic Talismanic Traditions in Nineteenth-Century Asante (Lewiston, I99I). 
powerful appeal of Aberewa and other savanna gods, the analysis of savannaforest interaction must be extended to those 'hinterland' peoples who hitherto have been swept to the margins of history. This article is an attempt to explore one discreet episode of a complex history of trans-regional ritual innovation in twentieth-century Ghana that has hitherto been obscured by the dominant narrative of conversion to Christianity. It also makes a case for the importance of thinking about the issues of witchcraft and anti-witchcraft as historical processes rather than a given set of structural beliefs and practices. We begin the story of Sakrabundi and its ritual 'offspring' Aberewa at the moment of colonial encounter: a first-hand account of a spectacular nocturnal dance on the northern fringe of the Akan forest in January I 889 .

THE 'GRAND FETish DANCE' A T OdUMASE, 6 JANuARY 1889

In December i 888 , a British mission from the Crown Colony of the Gold Coast set out for Bonduku, the capital of the kingdom of Gyaman on the northwestern frontier of the Asante empire. Strategically located astride one of the four 'Great Roads' fanning out from the imperial capital Kumase into the savanna, Gyaman was the northern-most outpost of Akan culture and state-craft. ${ }^{11}$ Aside from the Abron (or Bron) ruling class, the kingdom also contained an important population of Mande-speaking peoples, most notably Muslim Juula, as well as a variety of Gur-speaking savanna migrants such as Kulango and Nafana. The cosmopolitan commercial centre, Bonduku, had been the focus of intense diplomatic activity for over a decade. Gyaman had a long history of rebellion against Asante overrule, which made it a prime target of British efforts to bypass the authorities in Kumase in order to establish direct links with the northern provinces of the empire. ${ }^{12}$ Weakened by military defeat at the hands of the British in 1874 , by subsequent secessionist movements and by the descent into civil war in $\mathrm{i} 883$, the Asante government was fighting an uphill battle to maintain the wavering loyalty of Gyamanhene Kwaku Agyeman (r. I850-99). As recorded by medical officer R. Austin Freeman, the mission arrived in Kumase in late December, meeting briefly with the newly elected Asantehene Agyeman Prempe. ${ }^{13}$ It departed the war-ravaged capital on 28 December and on the morning of 6 January crossed the sacred Tano River as it headed northwest through the Bono-Takyiman kingdom. After a further seven hours march Freeman and his companions arrived at the settlement of Odumase. There they were greeted by a Muslim ambassador who had ridden the fifty miles down from Bonduku on horseback - 'indeed a welcome sight, for it showed us that we had really reached the limits of the dense forest.' ${ }^{14}$

11 The emergence and the precolonial political history of the Abron kingdom of Gyaman is examined in exhaustive detail by Emmanuel Terray, Une histoire du royaume abron du Gyaman: des origines à la conquête coloniale (Paris, I 995).

${ }^{12}$ For Asante-Gyaman relations in the $\mathrm{r} 870$ s to $\mathrm{r} 88 \mathrm{os}$, see ibid., 879-921; Wilks, Asante, 287-99.

${ }^{13}$ R. Austin Freeman, Travels and Life in Ashanti and Faman (London, I 898); official correspondence concerning the mission is located in Public Record Office, London (PRO) CO 879/28 Further Correspondence respecting the Assinie Boundary, Ashanti, Gaman, and Neighbouring Territories ( I 888-90).

${ }^{14}$ Freeman, Travels, 146. 


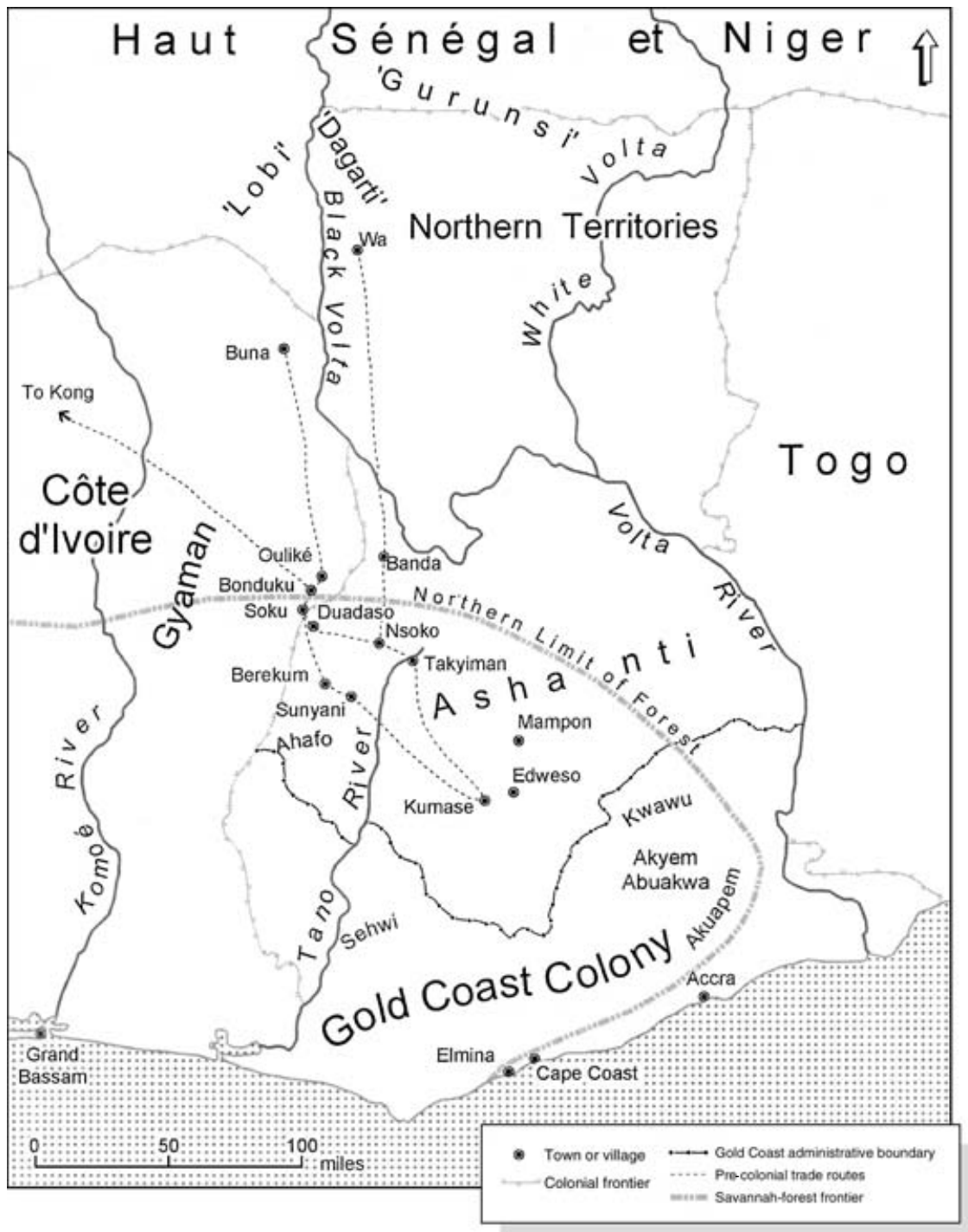

Fig. I. The Gold Coast and Eastern Côte d'Ivoire $c$. I 908.

That evening, Freeman writes,

a grand fetish dance was held in honour of our visit, and was really one of the most remarkable spectacles that I ever witnessed in West Africa. The deity worshippe[d] was the great inland fetish Sakrobúndi, or Sakrobudi, whose 'sphere of influence' appears to be very extensive, including Jáman, Gruinsi and several of the countries lying to the north. ${ }^{15}$

Sakrobu(n)di, Freeman was informed, was a new addition to the religious repertoire of Takyiman, having been introduced from the northern savanna

${ }^{15}$ Ibid., $\mathrm{I} 48$. 
in recent times. Although he had not encountered any trace of it in metropolitan Asante, 'in Jáman and the countries immediately to the north it was evidently held in great veneration' ${ }^{16}$ For Freeman, the one feature that set the 'fetish dance' apart from the ritual practices he was familiar with in the Akan kingdoms of the Gold Coast was the striking use of wooden masks:

The dancers were ... arranged in an incomplete circle ... and slowly revolved around its centre. The curved line was formed half of males and half of females and each of these divisions was 'sized' in a regular gradation ... All these performers were duly attired for the occasion. Most of them wore kilts of a soft flexible fibre ... and all had plaited armlets of the same material, with a long brush-like tassel, just above the elbows ... Several men were stationed in the interior of the circle and took an active, in fact I may say, agile part in the dance. The centre of the circle was, however, occupied by the most remarkable figure of the group, the principal fetish man ... He was enveloped from head to foot in a covering of the soft fibre of which the kilts were made, and to the front of this was attached a huge wooden mask in the semblance of an antelope's head surmounted by a pair of curved horns. The mask was painted red and white, the horns being decorated with alternate rings of these colours ... On the forehead a grotesque face was painted, and above this there were two holes for the fetishman to look through. ${ }^{17}$

'The dance itself', Freeman continues, 'was a strange and weird performance and altogether had quite an uncanny effect'. As the seventy or so dancers in the circle maintained a steady, hypnotic rhythm ("they kept as perfect time as a company of highly drilled soldiers ... so the effect was that of an immense machine'), those at its centre performed 'with the greatest animation'. They included one of the mission's local guides, 'my friend Koffi Dabbi, whose athletic figure and remarkable activity enabled him to take a part in the performance that reflected credit upon the expedition'. Meanwhile, the heavily masked 'fetish man'

capered about with surprising agility, running to and fro inside the circle and occasionally kneeling on the ground at its centre ... Now and again he retired to an adjacent fetish house to perform some occult part of the ceremony ... whence he presently returned to renew his gambols. He was armed with a small switch with which he occasionally stimulated the devotion of his flock, and was attended by a species of acolyte who arranged his robe and adjusted his mask from time to time ... [I]t was easy to see that he was regarded with no small awe, for whenever he approached the confines of the ring the dancers fell back with an expression of fear. ${ }^{18}$

16 Ibid.

${ }^{17}$ Ibid., I 50-2. An extremely rare example of such a mask, collected by British official C. H. Armitage in the early twentieth century, can be seen in the new African gallery of the British Museum in London; on this mask, see Tom Philips (ed.), Africa: The Art of a Continent (Munich, 1999), 452-3.

${ }^{18}$ Freeman, Travels, I 53-4. It may be noted here that the role of dance in ritual practice in Africa has received little attention from historians: see the comments by Louis Brenner, " "Religious" discourse in and about Africa', in Karin Barber and P. F. De Moraes Farias (eds.), Discourse and its Disguises: The Interpretation of African Oral Texts (Birmingham, I989), 96. For recent insights into the nature of the encounter between European expeditions and Africans in the period of colonial expansion, see Johannes Fabian, Out of Our Minds: Reason and Madness in the Exploration of Central Africa (Berkeley, 2000), esp. ch. 5, 'Things, sounds and spectacles'. 
The British mission departed Odumase the following morning. It continued to encounter the presence of Sakrabundi (as the deity is named in later sources) on the road into Gyaman, once at Soku, where it camped next to a grove dedicated to the god, and again at Duadaso ('Diádasu'), where Freeman observed two further variations of the horned mask that had captured his imagination on the night of 6 January. He and his companions would spend two months in Bonduku, engaged in intermittent negotiations with the Gyamanhene on the issue of British 'protection'. Ultimately, these negotiations would prove fruitless. Agyeman was also treating with a rival French expedition headed by Louis Binger and four years later, in $\mathrm{s} 893$, it would be French rather than British or Asante protection that he would finally accept. ${ }^{19}$ French protection was found sorely wanting two years later, however, when Bonduku was occupied by the forces of yet another would-be empire builder, the Juula warrior Samori Ture. In I 896 - partly in response to the threat posed by Samori-British forces occupied Kumase itself, leaving Bonduku and most of Gyaman separated from the rest of greater Asante by the colonial frontier dividing Côte d'Ivoire and the Gold Coast.

The r 888-9 British expedition remains a minor footnote in the history of the European scramble for territory in this corner of West Africa in the last quarter of the nineteenth century. Yet Freeman's account of the appearance of a 'great inland fetish' on the northern fringes of the Akan forest lends itself to a different, if not entirely unrelated, historical narrative: that of the shifting ritual landscape of nineteenth- and twentieth-century Ghana. Its only significant appearance in the secondary literature is in the work of Rene Bravmann, who analyses the eruption of savanna-style zoomorphic masquerade into the Bron region of the Akan world from an art historical perspective. ${ }^{20}$ Freeman's description is cited in passing by Goody as evidence for an underlying continuity in the passage of ritual power from the savanna to Asante. ${ }^{21}$ Yet Goody's argument that exotic anti-witchcraft movements may therefore have been as commonplace in precolonial Asante as they were in the twentieth century is as speculative as that which assumes that such movements were the product of colonial rule. There is every indication that the only documented precolonial example, Domankama, was a home-grown phenomenon, drawing its ritual power from the deep forest and its ideological inspiration from the founding charter of the Asante state. The fact is that Freeman's encounter with Sakrabundi in I 889 represents the earliest known evidence for the passage of a witch-finding deity and its associated cult across the ecological and cultural frontier separating the savanna world in the north from the Akan forest zone in the south. His evidence that it came from 'Gurunsi' territory to the north demands some reconsideration of the historical relationship between the Asante centre and its savanna periphery.

19 For Binger's account of Bonduku and Gyaman - which makes no reference to the Sakrabundi cult - see L. G. Binger, Du Niger au Golfe de Guinée : par le pays de Kong et le Mossi (Paris, I 892), I 45-87.

20 René A. Bravmann, Islam and Tribal Art in West Africa (Cambridge, 1974); idem, 'Gur and Manding masquerades in Ghana', African Arts, I3 (1979), 44-5 I ; and idem, Open Frontiers: The Mobility of Art in Black Africa (Seattle, I973).

21 Goody, 'Anomie', 359. 
Asante perceptions of the northern savanna grasslands (Twi: sarem; cf. kwaem, 'the forest') were characterized by a wide variation in the degree of civilization accorded to its inhabitants. While the rulers of the Gonja and Dagomba conquest states were regarded as alien outsiders, they possessed recognizable political hierarchies and by the mid-eighteenth century were incorporated into the expanding imperial system by formal treaty arrangements. From these savanna polities as well as the far-flung Juula and Hausa trading diasporas came peripatetic merchants and Muslim scholars and diviners who were given special leave to settle in Kumase and who provided crucial services for the Golden Stool. ${ }^{22}$ In contrast, the non-centralized 'tribal' peoples of the middle Volta basin were generally regarded as uncivilized barbarians, fit only to be exploited as slaves. These peoples were called 'Gurunsi', a pejorative generic ethnonym borrowed from the MossiDagomba state-builders, or nnonksfos (sing. sdsnks), a term that suggested a servile identity on the very lowest rung of Akan perceptions of humanity. ${ }^{23}$ Yet this acknowledged lack of civilization appears to have given rise to a deep ambivalence in Akan attitudes towards the stateless denizens of the Sarem frontiers. The Gurunsi and other nnonksfor may have been seen as uncouth primitives who inhabited an untamed wilderness beyond the bounds of human culture. But they were also seen to possess access to an array of the most potent ritual powers, together with the esoteric knowledge necessary to mobilize them in defence of the cultural order. This perception was fuelled by the belief that the Akan's own tutelaty deities, the abosom, were simply too 'lofty' to be much use in the grim quotidian battle against maleficent witchcraft or bayi. What was necessary for this task was protection from a lower category of ritual powers, the asuman (sing. suman). Volatile, capricious and notoriously difficult to master, the asuman were seen to be so effective precisely because they were themselves derived from the same untamed forces of nature that gave rise to bayi. ${ }^{24}$

Freeman makes no mention of witchcraft as having anything to do with the spectacle he witnessed in I 889. It is only when the 'great inland fetish' reappears in the historical record of the opening phase of the French occupation of Gyaman that it emerges as a god devoted to the ruthless defeat of witchcraft. ${ }^{25}$ In the context of the consolidation of colonial conquest, it is also portrayed as an altogether more threatening and potentially subversive force. In I 902, Sakrabundi was encountered by a young Maurice Delafosse during the demarcation of the colonial frontier between Côte d'Ivoire and the Gold Coast. Despite - or perhaps in part because of - the political turmoil of the previous decade and the destruction wrought by Samori's sofas, the cult continued to dominate the ritual landscape of the region. The pioneering administrator-ethnographer provides a detailed description of the shrine

22 See the references in $n$. Io.

23 On the situation of and perceptions of nnonksfor in Asante, see McCaskie, State and Society, 95-го .

${ }^{24}$ For a fuller treatment of this issue, see Allman and Parker, Tongnaab.

25 See the account by Marcel Monnier, a member of Binger's French contingent of the I 892 Anglo-French Boundary Commission, in France noire (Côte d'Ivoire et Soudan) (Paris, I 894), I 66-70. 
complex devoted to Sakrabundi ('Sakara-Bounou') at the predominantly Nafana village of Oulike (or Wirekye) ten kilometres to the north of Bonduku. ${ }^{26}$ Unlike Freeman, Delafosse understood that what the deity did was to offer ritual protection against evil and misfortune. Yet he took an entirely negative view of the cult. In what would become familiar in subsequent anti-witchcraft movements in the Gold Coast, individual protection together with the social harmony of the community was secured by the ingestion of a specially prepared sacramental liquid. Not only would this initiation rite identify witches and cure them of their affliction, it thereafter bound all adherents - on pain of death at the hands of the god - to abide by a corpus of moral laws, most prominently a strict prohibition on the practice of witchcraft or sorcery. Herein lay the moral ambivalence that ultimately would bring Sakrabundi, Aberewa and their successors into conflict with both local African rulers and the colonial state. That is, local deaths were often attributed to the watchful god, with the deceased identified either as an sbayifo or someone who otherwise had contravened the laws of the cult. To suspicious outside observers, however, the sacred infusion was believed simply to be a poison targeted especially at wealthy victims, whose property passed to the officiating 'fetish priests'. Thus, Delafosse in I 902 regarded Sakrabundi as nothing more than a murderous extortion racket, responsible for the poisoning of large numbers of people who refused to join its ranks.

Thirteen years earlier, Freeman had expressed considerable interest in Sakrabundi's origins. Unfortunately, his questions on the matter were frustrated by a combination of language difficulties and local suspicion regarding the motives of the British diplomatic mission, 'besides which African natives are as a rule extremely reticent on the subject of religious beliefs, and ... moreover, their own ideas on religious subjects are commonly extremely vague and indefinite'. ${ }^{27}$ There may be more to this comment than late Victorian condescension towards 'primitive' belief. Imprecision and uncertainty does cloud many indigenous accounts of the provenance of exotic witch-finding gods - a fact that serves to underline their essentially protean, amorphous nature. A fundamental ideological adaptability meant that such gods tended to mutate over time and space, acquiring new accretions to their ritual personality as they traversed cultural and political boundaries. As would be the case with the diffusion of Sakrabundi and Aberewa into the Gold Coast, new deities were often deliberately marketed from an intermediary shrine centre as being from some ill-defined nether-region. The further they travelled the more elaborated these rumours of provenance often became.

Freeman's guess was that Sakrabundi had been introduced into Gyaman 'possibly from Gruinsi [i.e. Gurunsi], Moshi, or Dagomba'. ${ }^{28}$ This may have been correct only insofar as 'Gruinsi' and 'Moshi' are taken vaguely to refer

26 M. Delafosse, Les frontières de la Côte d'Ivoire, de le Côte d'Or et du Soudan (Paris, I908), I I 9-2I. Rendered variously as Oûrigué (by Delafosse), Ouliké, Welekei and Wirekye, the village was also called Soumbala by the Juula. Typically for Gyaman, it comprised distinct Nafana, Abron and Kulango quarters.

27 Freeman, Travels, I 48. 
to lands to the north, while Dagomba, which has no masking tradition, seems highly unlikely. A more probable ritual passage is via one of the two welltravelled trade routes connecting Bonduku with Buna to the north and Kong to the northwest. The three towns were in the nineteenth century important centres of the Juula trading diaspora and all were characterized by a high degree of cultural dialogue between resident Muslim communities and indigenous non-Muslim populations. Thus, the three distinct Muslim Mande groups settled amongst the Akan- and Gur-speakers in Gyaman, the Juula, Ligbi and Hwela practised their own masquerades aimed at controlling witchcraft, Gbain and Do. These were 'power associations' which in their original manifestations in the Mande heartland far to the west were (and remain) essentially non-Muslim. ${ }^{29}$ By the early twentieth century at least, Do and other anti-witchcraft masks had in turn been transmitted from the Mande diaspora to the Akan-speaking Baule region of southern Côte d'Ivoire, where they became known as bonu amwin. ${ }^{30}$ That Sakrabundi (or 'Sakara bonu') drew at least some inspiration from these sources is further suggested by the word sakara itself, a key Juula ritual term that defies exact translation but can be rendered broadly as 'sacrifice'. ${ }^{31}$ A Mande origin is also stressed in oral traditions about Sakrabundi told to Eva Meyerowitz in the Bron states of Takyiman and Wankyi in the r94os. In an intriguing contrast to Freeman's account, her informants suggest that Sakrabundi was once a hallowed state abosom of the Bono (or Bron) kingdom. Losing royal patronage, it had become a lesser 'antelope god' and had fallen back on the 'smelling out' of witches - the heterodox manifestation confronted by Freeman in $1889 .{ }^{32}$

Further crucial evidence is provided by another of French West Africa's famous administrator-ethnographers, Louis Tauxier, who conducted detailed research into the cultures of Gyaman in the late r 9ros. In Le Noir de Bondoukou, Tauxier paints a picture of a complex ritual landscape in which apprehension concerning the destructive powers of witches ('les sorciers ou mangeurs d'âmes', i.e 'soul eaters') was omnipresent and long-standing dialogue between the diverse peoples of the region had resulted in the mutual

${ }^{29}$ On Gbain (or Gwan) and Do (Jo) as practised by the Mande in Gyaman in the r 960 , see Bravmann, Tribal Art; on their manifestations amongst the Bamana of Mali, see Pascal James Imperato, Buffoons, Queens and Wooden Horsemen: The Dyo and Gouan Societies of the Bambara of Mali (New York, 1983 ).

${ }^{30}$ See Herbert M. Cole, 'Akan worlds', in Monica Vinsonà et al. (eds.), A History of Art in Africa (New York, 2001), 21 9-20.

${ }^{31}$ Robert Launay, Beyond the Stream: Islam and Society in a West African Town (Berkeley, I992), I96-219 and 235 n. 7, which observes that Senufo 'pagans' (of whom the Nafana represent the eastern-most extension) have in the Kong region borrowed the term sakara from the Muslim Juula. Delafosse, Les frontières, ı 08 , noted that Sakrabundi reached from the heart of Senufo country, through Asante and on to the coast. Intriguingly - given Sakrabundi's subsequent transformation into Aberewa - the male elders of Poro, the leading Senufo power association, are known collectively as katyeleeo, 'The Old Woman' or 'The Ancient Mother': on Senufo masking traditions, see Anita Glaze, Art and Death in a Senufo Village (Bloomington, I981).

${ }^{32}$ Eva L. R. Meyerowitz, The Akan of Ghana: Their Ancient Beliefs (London, 1958), I24. Meyerowitz's informants, principally Wankyihene Kwame Abrafa V, took a hostile position towards the remnants of Sakrabundi's power in the region in the I940s, stressing that unlike other gods, its sacred water was indeed poisonous. 
adoption of a range of powerful protective deities. ${ }^{33}$ The battle against witchcraft was led by a group of ferocious witch-finding gods named Pakalagui, Kabelinga, Gourouhui and, most formidable and widespread of all, Sakrabundi ('Sakarabouri'). Tauxier was unsure about the origins of the latter, suggesting tentatively that it may well have been an ancient Abron deity. But he was certain on two fundamental characteristics of Sakrabundi and its fellow ' grands fétiches personalisés'. First, far from being the cynical extortion racket out to dupe cowering locals decried by Delafosse, Sakrabundi was a dedicated - if ruthless - upholder of the most fundamental moral values. 'It is pointless to say that all of the psychology of Sakarabrou or Sakarabouri is false', he wrote with some insight. 'Sakarabouri is an authentic god [une divinite authentique], symbolising forces that are essentially good, moral, terrible to sinners and the enemies of witches'. ${ }^{34}$ Second, that the widespread diffusion of the witch-finding gods was facilitated by the fact that they were fully commodified ritual resources. An integral part of the new colonial cash economy, they could be bought and sold with ease, moving along trade routes and across a variety of cultural, political and ecological frontiers. ${ }^{35}$

The archival record contains two revealing indigenous narratives of the diffusion of Sakrabundi's 'offspring' Aberewa into metropolitan Asante in I 906-7. Such nuanced accounts of the shifting ritual landscape of early colonial Asante are rare, so it is worth citing them at some length. 'It is related that Aberewa comes from Bona [i.e. Buna] country', wrote Reverend N. V. Asare, a pastor of the Basel Mission at Kumase and an insightful observer of local affairs.

Once upon a time, an old woman fell sick and died at Bona country. Her dead body was prepared and buried. When she was going to hell, a respectable man whose duty was to guard the gate of hell met her at the entrance, the moment the old woman arrived at the place, the said man bade her to go back to the World because her time of coming to hell is not due yet, for she died untimely as she was hated and bewitched by others. But before she returned, the man gave her a certain charm or fetish [i.e. suman] in connection with a medicine by the effect of which, nobody in the World would be able to poison or kill her. She would grow to great age and then dies natural death $[$ sic $]$ after all ... [S]he arose and returned alive to the World and related the whole story to her country men and since then her fetish and medicine which she brought from hell were worshipped in the country of Bona. ${ }^{36}$

${ }^{33}$ Louis Tauxier, Le noir de Bondoukou: Koulangos, Dyoulas, Abrons, etc. (Paris, I $92 \mathrm{I}$ ), esp. 172-205, passim, on Kulango religion. On the high degree of cross-cultural religious interaction in the region, see too Paul Marty, Etudes sur l'Islam en Côte d'Ivoire (Paris, I 922), 2 I 6-42, 4IO-34.

${ }^{34}$ Tauxier, Le noir de Bondoukou, 190.

${ }^{36}$ Regional Archives of Ghana, Kumase (RAG), Ashanti Regional Government (ARG) I/30/I/6 Chief Fetish Priest 'Abirewa', 'Story about Aberewa', by N. V. Asare, dd. Kumase, 6 Mar. I 907. A later version of this text with added material appears in Basel Mission Archive, Basel, Switzerland (BMA) D-I,86/ı 32, Annual Report about Kumase Congregation, by N. V. Asare, 30 Mar. 1907. On Rev. Asare's crucial role in the production of knowledge about Asante during the first decade of colonial rule, see T. C. McCaskie, 'The Golden Stool at the end of the nineteenth century: setting the record straight', Ghana Studies, 3 (2000), 6 $1-3$. For a Kong rather than a Buna origin, see Arthur Ffoulkes, 'Borgya and Abirwa; or, the latest fetich [sic] on the Gold Coast', Fournal of the African Society, 8 (1908-9), 388. 
Asare's text can be compared with an alternative account by his fellow Basel Mission scholar, schoolteacher Ben Ampofo from Edweso:

Once upon a time there lived in a village of Wireche [i.e. Oulike] situated in the British [sic] Gaman a man called Sie Quaku who took [a] walk on the street one day. In his reaching of a certain place he saw a big ball like a head laying down. 'What is this black ball?' he questioned himself. And to his great surprise the ball answered: 'Take me home'! 'Why may I carry you home for?' asked the man. The ball replied with a very distinct voice that: 'You must carry me home! For I am a very strong power sent from the heaven by the Creator [i.e. onyame or domankama] unto you all. Because the Creator had from the commencement of creation fixed the fate of every creature that all may depart from this world in their old ages with gray hairs to heaven; but now [a] lot of the creatures had come to us ... without [having] been called and we learnt from them they were sent out from this world so prematurely by witches and poisoners. Therefore I am the strongest medicine sent to this world and whoever will drink some shall never be perished prematurely by witchcrafts and poisoners ...' Then the man took the ball to his house and when he opened it the contents were black powdered medicine [Twi: bofo].

Sie Quaku then kept this medicine in his house for some time. But as he did not know how to use it, it is said it killed a great many of his relatives. Therefore he intended to throw it away, but a friend advised him to ... enquire the use of it from the most powerful Mohamedan priest and some strong fitish [sic] priests. From these different priests he learnt how to worship this ball hereafter called 'Aberewa' (old woman). It was named 'Aberewa' because she is coming to look for her creatures as an old woman cares for her young seeds. It was also surnamed 'Sakrabudi' because she is coming to change the sin which is on the earth ('sakrabudi' means 'sakrabone' or change the $\sin ){ }^{37}$

A number of key differences between these two narratives are worth exploring. Whereas Ampofo locates the 'arrival' of Aberewa in Gyaman, Asare traces it to the more distant Buna. Others in turn (including, as we will see, Osei Kwaku - 'Sie Quaku' - himself) would identify 'Dagarti' country to the north of Buna as the source. Aberewa's emergence from 'hell' in the one text and from 'heaven' in the other is also intriguing, but is perhaps easy to overstate. The question of the impact of Christian doctrine on the translation and transcription of 'traditional' ideas regarding witchcraft and anti-witchcraft - as well as on the actual content of those ideas - is an important one. ${ }^{38}$ Yet rather than indicating an eschatological divergence, it seems likely that both terms were used simply as alternative translations for the Akan afterworld, asaman. Perhaps more interesting is Ampofo's story of the destruction wreaked by Aberewa on Osei Kwaku's family before it had been

${ }^{37}$ RAG ARG I/30/I/6, 'Some details about fitich [sic] Aberewa', by Ben Ampofo, n.d. [but 1907]. The Twi verb sakra or sakara: 'to change' or 'to alter', also used by Basel Mission linguists to convey religious conversion; bòné: evil, wickedness or 'sin': see Rev. J. G. Christaller, A Dictionary of the Asante and Fante Language Called Tshi (Chwee, Twi) (2nd edn., Basel, i 933). Both accounts were drawn on by Rev. A. Bauer and Rev. J. S. Ellenberger, 'Aberewa: a new and dangerous religion', Foreign Field, 4, 4I (Jan. I 908), I60-2, and 42 (Feb. I908), 208-10, a collaborative piece by representatives of the Gold Coast's two principal Christian missions, the Basel Mission and the Wesleyan Methodist Missionary Society.

${ }^{38}$ It is examined most fully in Birgit Meyer, Translating the Devil: Religion and Modernity among the Ewe in Ghana (Edinburgh, 1999). 
tamed by the combined intervention of Islamic and indigenous ritual knowledge. Aside from representing a graphic example of the highly dangerous, ambivalent nature of asuman, this also hints at the close interaction between the two ritual realms.

Finally, a comment on the names of the two gods. It is apparent that the term Sakrabundi and its alternative forms could be either Mande or Akan in origin. In contrast, aberewa is unambiguously an Akan word. But it encapsulates the profound ambivalence that characterizes indigenous understandings of bayi. Despite Ampofo's emphasis on the protective, nurturing role of old women, the term is also highly suggestive of the imperative to engage with the perceived agents of affliction in the battle against witchcraft. Old women were indeed nurturing, but they were also regarded by many as the most dangerous and hostile of abayifos. This tension would emerge at the heart of the historical experience of Aberewa in Asante and the Gold Coast. More broadly, it was the gender dynamics of the movement that most visibly distinguished it from established Mande and Senufo power associations specializing in protection against witchcraft. Whereas the latter tended to take the form of 'secret societies', with membership restricted to male elders only, Sakrabundi/Aberewa was open to men and women of all ages. As indicated by Freeman's i 889 account and later confirmed by Tauxier, women were especially prominent in the cult's ritual practice - a crucial innovation in its ritual passage from the savanna world to the Akan forest.

ABEREWA IN ASANTE AND THE GOLD COAST, 1906-10

In I 906, Aberewa exploded out of the cultural crossroads of Gyaman into the Akan heartland. For the first time since the brief efflorescence of Domankama in I879-80, a popular anti-witchcraft movement had taken hold in metropolitan Asante. In the states of the Gold Coast Colony to the south, no comparable cultic association appears to have emerged in the past. To what extent did the sudden expansion of Aberewa result from the imposition of colonial rule?

For Asante at least, the timing is certainly suggestive. Aberewa swept through Asante ten years after the arrest and removal of Asantehene Agyeman Prempeh by British forces in 1896 and just five years after the defeat of the Yaa Asantewaa uprising and the formal annexation of the kingdom in I90I. On the supply side of the expanding trans-regional commerce in ritual goods and knowledge, there can be little doubt that the imposition of colonial peace greatly facilitated the movement of the cult across what had since i 874 been an armed frontier between 'rebel' Gyaman and Asante. Shifting patterns of demand are more difficult to determine. The documentary record contains some indications that the termination of Asante sovereignty did trigger a widespread sense of dispossession, anxiety and apprehensionfeelings of unease that were expressed in the established idioms of bayi. 'Formerly Prempeh was our protector', one resident of Kumase proclaimed in I 908 , 'but as he is no more among us, a new and strong protector [has] been give[n] to us in Aberewa'. ${ }^{39}$ Interviewed in r 945, Akosua Pokuaa of the

${ }^{39}$ Cited in RAG ARG I/30/I/6, F. Ramseyer to Fuller, 22 July i 908. 
village of Adeebeba near Kumase recalled how in the first years of the new century the land seemed to be 'filling up with a rising tide of witches' ${ }^{40}$ Tauxier recorded similar fears on the other side of the border in French Gyaman, where a perceived intensification in the nocturnal activities of witches in the immediate aftermath of colonial conquest resulted in a further expansion of Sakrabundi and the other great anti-witchcraft deities. ${ }^{41}$

The notion that the shock of colonial conquest triggered a generalized psychological dissonance works less well for the Gold Coast Colony, where many African states and societies - especially those on the Atlantic seaboard experienced a prolonged, negotiated transition to British colonial rule stretching back to the mid-nineteenth century. ${ }^{42}$ Yet there can be little doubt that on the Gold Coast as well as in Asante, the sudden expansion of the colonial cash economy fuelled by the take-off of cocoa exports in the rgoos served to deepen existing social tensions while at the same time creating a whole raft of new problems and anxieties. ${ }^{43}$ Moreover, at the very moment that economic and social change began to accelerate, the colonial state removed the power of indigenous rulers to detect and punish offences concerning the practice of bayi. Having already confiscated 'the knife' and prohibited trial by ordeal, the British in I90 I suppressed afunsua or 'coffin carrying', the funerary ritual by which suspicious deaths apparently involving the use of bayi or magical 'poison' (aduto or aduru bone) were investigated. ${ }^{44}$ The widespread desire to reconstruct a sense of community based on the well-enforced moral certainties of the past emerges most explicitly in the ubiquitous lists of 'commandments' that Aberewa adherents were bound to observe - on pain of death at the hands of the vigilant god. These typically extended from a strict prohibition on the use of bayi and aduto through to injunctions against theft, extortion, adultery, excessive litigation, envy and quarrelling, and on to the insistence that neighbours and family assist each other in trade and agricultural ventures. ${ }^{45}$ What is particularly striking about these commandments is the way in which so many made explicit reference to moral issues arising from the process of individual accumulation.

To explain the spread of organized witch-finding from Gyaman, however, we must look beyond the sociological background to the agency of individual historical actors. The key figure in the diffusion of first Sakrabundi and then Aberewa was Osei Kwaku, the 'priest' of the shrine centre at Wirekye north of Bonduku. Ben Ampofo's hearsay version of the discovery of Aberewa seems to locate the episode in the distant, almost mythological, past. But this

${ }^{40}$ Ashanti Social Survey Papers, as cited in T. C. McCaskie, Asante Identities : History and Modernity in an African Village 1850-I950 (London, 2000), 184-5.

41 Tauxier, Le noir de Bondoukou, I 84-5, 195.

${ }^{42}$ See, for example, John Parker, Making the Town: Ga State and Society in Early Colonial Accra (Portsmouth NH, 2000).

43 The literature on the cocoa economy of the colonial Gold Coast is extensive, but for its social impact on one Asante community, see McCaskie, Asante Identities, I24-200 passim.

${ }^{44}$ National Archives of Ghana, Accra (NAG) ADM II/I/I 437, Suppression of Objectionable Customs, compiled by S. D. Codjoe, n.d. [c. I 930], 'Afunsoa custom'.

${ }^{45}$ See esp. Debrunner, Witchcraft, I I 2-I6, citing Rev. O. Lädrach, Der Sturz eines afrikanischen Lügengottes (Basel, I 919). 
is misleading, as in May I907 the commissioner of the Western District of Ashanti, T. E. Fell, actually met and interrogated Osei Kwaku in Sunyani town during the course of his investigations into the origins of the movement. Osei Kwaku confirmed that after a sustained attack on his family by bayi 'many years ago' that resulted in a series of calamitous deaths, he 'heard of this Fetish in Dagarti Country and went to consult the Priest'. He returned 'carrying Sakrabudi on his back, so he said, and Abirewa in front'. ${ }^{46}$ 'Dagarti country' refers to the territory north of Buna of the Lobi and Dagara peoples, identified by outsiders as an especially primitive, hostile and isolated branch of the Gurunsi 'pagan tribes'. ${ }^{47}$

Accounts differ as to whether the two asuman were in fact distinct deities or merely a deliberate remarketing of the same ritual power by the entrepreneurial Osei Kwaku. 'I am of opinion that Sei Kwaku ... recently coined "Abirewa", ', Fell reported, 'as "Sakrobudi" was becoming unfashionable and was not so lucrative as it used to be'. ${ }^{48}$ Be that as it may, we know that the latter had reached the Tano River in Takyiman by i 889 . Some ten years later, it was purchased from Osei Kwaku by leading figures in Sunyani-having apparently shed the dramatic masked dances recorded by Freeman. According to one practitioner, the okyeame or state linguist of Sunyani, Sakrabundi 'spread all over the country to the Coast'. In Sunyani itself, 'it lasted as a fashion for 6 years or so and died out' before being supplanted by Aberewa. ${ }^{49}$

Aberewa's main point of diffusion into Asante was not the god's sacred centre in French Gyaman but an intermediate shrine established in about I 905 across the border at the town of Takyiman. Osei Kwaku placed this ritual staging-post under the control of two 'deputy priests' named Yaw Atoa and Yaw Nokwobo, the latter a Gurunsi ex-slave who would make a powerful impression in Kumase over the coming years. It was from there that the physical suman together with the esoteric knowledge necessary to activate it was purchased by office-holders and by consortiums of 'commoners' from throughout Asante. ${ }^{50}$

It may be difficult to document any definitive link between the advent of colonial rule and that of Aberewa. But there can be no doubt that the history of the movement was intimately shaped by the post-conquest political landscape of Asante. Like Domankama in 1879, Aberewa emerged in metropolitan Asante at a time of rising tensions within the political order. By I905, popular forces began to mobilize against a clutch of office-holders illegitimately appointed in the aftermath of the Yaa Asantewaa uprising.

46 RAG ARG i/30/I/6, 'Aberewa fetish', by T. E. Fell, dd. Sunyani, 26 May i 907.

47 It was also the origin of the later anti-witchcraft movements Kunde and Kankamea. For indigenous perceptions of 'primitive tribes', see for example PRO CO 879/37, Further Correspondence respecting the Assinie Boundary, Gaman, and Neighbouring Territories, Report by J. I. Lang, I 7 Nov. I 892 (reporting Abron views of the Kulango of Buna); and Delafosse, Les frontières, I 38 (reporting, in turn, Buna-Mansa Dari Ouatara's dim view of the Lobi).

48 RAG ARG I/30/I/6, Fell to chief commissioner of Ashanti (CCA), dd. Sunyani, I June I 907.

49 RAG ARG I/30/I/6, statement of the linguist of Sunyani, n.d. [1907]. For further evidence that Sakrabundi had reached the coast by i 902, see Delafosse, Les frontières, io8.

50 RAG ARG I/30/ı/6, 'Story about Aberewa', by N. V. Asare. 
Prominent amongst these figures was Yaw Awua, a long-standing opponent of the pre-1 896 Kumase regime who in I $90 \mathrm{I}$ was rewarded for his loyalty to the British cause with the vacant stool of Edweso. ${ }^{51}$ In i 906, Edwesohene Yaw Awua became the first Asante chief to acquire Aberewa after hearing rumours of this powerful new suman in the Wankyi town of Nsoko. ${ }^{2}$ Seemingly eager to bolster his ritual armoury in the face of popular hostility, he became a leading champion of the new movement. Aberewa's subsequent diffusion from Edweso was so rapid, however, that it could not be controlled by the office-holding elite. In many of Asante's constituent divisions it took the form of a genuinely popular movement and was perceived by chiefs - especially those whose claims to office were tenuous at best - as a real threat to their authority. This was the case, for example, in Mampon, where Mamponhene Kwesi Sekyere attempted unsuccessfully to prohibit the movement, and in Agona, whose embattled omanhene Kwame Boakye associated Aberewa with the forces attempting to destool him. 'I cannot bring any specific charges', Bantamahene Osei Mampon reported from Kumase, 'but those of my people who have accepted the Fetish no longer visit or salute me'. ${ }^{53}$

In both geographical reach and numbers of adherents, Aberewa therefore operated on a far larger scale than Domankama. By mid-I907, Yaw Awua reckoned that some 6,000 of his subjects had joined the movement. ${ }^{54}$ This figure may well have been inflated in the light of Yaw's role as a pioneering patron of Aberewa, but it is not wildly out of line with reports from other chiefs who were openly hostile to the new cult. From Asante it then continued on to the Gold Coast, moving into the eastern Colony via Kwawu, whose famously peripatetic traders would continue to act as key agents in the transmission of ritual commodities throughout the colonial period ${ }^{55}$ In the Gold Coast kingdom of Akuapem - also an early stronghold of Christianity due to the long-standing presence of the Basel Mission - the omanhene estimated in I9I 3 that 'almost half of the heathen population ... have partaken of the notorious drug or medicine' ${ }^{56}$ Such was the popular enthusiasm for this exotic savanna god that alarmed Christian missionaries believed they were dealing with a whole 'new religion'. 'Even Muhammadanism is not to be feared as much as this', one warning ran, 'for the people are becoming completely spellbound beneath it, drawn by its promises of immunity from all pain, or terrified by its threats of a horrible death'. ${ }^{57}$

${ }^{51}$ There is still no sustained treatment of the opening years of colonial rule in Asante, but see William Tordoff, Ashanti under the Prempehs, I888-I935 (London, I965), I 48-66; McCaskie, 'The Golden Stool', 85-96; idem, 'Anti-witchcraft cults', I 38-4I ; and on Yaw Awua, Ivor Wilks, Forests of Gold: Essays on the Akan and the Kingdom of Asante (Athens OH, I993), г69-88.

${ }^{52}$ PRO CO 96/47I, Governor Rodger to Crewe, secretary of state for the Colonies, I 7 Aug. 1908, enclosed: 'Palaver held on the 3 rd August 1907 in connection with ... the “Abirewa fetish" worship', evidence of Yaw Wua, and of Kwamin Dente of Nsoko. All subsequent $\mathrm{CO} 96 / 47 \mathrm{I}$ citations refer to enclosures in this dispatch.

${ }^{53}$ Ibid. ${ }^{54}$ Ibid.

55 NAG ADM I I/I/I I 54 Abrewa [sic] fetish, I9I2, 'Information regarding the fetish Aberewa', by Owusu Ansa, Omanhene of Akuapem, n.d. [but I9I3].

${ }^{56}$ Ibid. ${ }_{57}$ Bauer and Ellenberger, 'Aberewa', 2 I 0. 
Missionary denunciations must be treated with caution when considering the perceptions of the movement's acolytes. But, as the Reverends Bauer and Ellenberger indicated, Aberewa did possess two quite distinct aspects to its divine 'personality'. One was male and was known either as Manguro or Burogya; the other, female, aspect was Aberewa, 'The Old Woman'. ${ }^{8}$ This gendered distinction was central to the cult's innovative approach to the problem of bayi. In short, it worked on what might be described as the 'good cop, bad cop' model: while Aberewa possessed the power to cleanse abayifor and to reintegrate them into human society, Manguro or Burogya was obrafo, 'the executioner', visiting death on those who transgressed the strict moral code of the reborn community. The Aberewa movement as a whole appears therefore to have represented a further shift in anti-witchcraft strategy amongst the Akan, from the state-sanctioned punishment of precolonial times to community-based healing. This may have been due in part to African rulers having lost the power to impose capital punishment coupled with the refusal on the part of the colonial state to recognize witchcraft as a reality and therefore as a punishable offence. But the shift from punishment to healing was clearly only partial-as is indicated by the deaths of unrepentant abayifos and other transgressors claimed to have been caused by the god. As Ben Ampofo explained, 'it seems the chiefs who buy this fitish to their villages intend to win back the old executive knife by [using]... Aberewa to kill anyone who disobeys the chiefs or commits a slight fault' ${ }^{59}$ Aberewa's ambivalent nature goes some way to explaining the very different ways that the cult was perceived - by both Africans and Europeans. If one focused on its healing, female role (as Tauxier did, for example, with regard to Sakrabundi in French Gyaman), then the movement could be seen as an essentially positive phenomenon. If one chose to focus on the vengeful, male aspect (as we have seen in the contrasting account by Delafosse), then whether or not the observer 'believed' in power of the god - the movement could be reduced to little more than an instigator of death and destruction. This ambivalence was captured neatly by Nathanael Asare in I 907. 'Aberewa is considered as a life giver or preserver of life', he wrote, 'and therefore kills all those who intend to damage the life of others' ${ }^{60}$

The crucial distinction between male and female power was reflected in the configuration of the shrines that from I906 began to spout like mushrooms on the kurotia - the ritually charged liminal zone between the realms of culture and nature - on the outskirts of towns and villages throughout Asante and the Gold Coast. Aberewa tended to be installed in a circular shrine at the eastern side of a settlement, Manguro or Burogya in a rectangular structure to the west. These were often impressive buildings, described by District Commissioner Ffoulkes as 'very superior to the usual shelter of a few palm-leaves put over... fetiches' and indicative of the high levels of revenue accruing to the cult's local mediators. ${ }^{61}$ The physical

58 See Christaller, Dictionary, 309; Ffoulkes, 'Borgya and Abirwa'; Bauer and Ellenberger, 'Aberewa'.

59 RAG ARG I/30/I/6, 'Some details about fitish Aberewa'.

60 Ibid., 'Story about Aberewa'.

61 Ffoulkes, 'Borgya and Abirwa', 389; see too BMA D-I,88/15, Annual Report of Kumase Congregation for 1907, by N. V. Asare, 29 Feb. I908. 


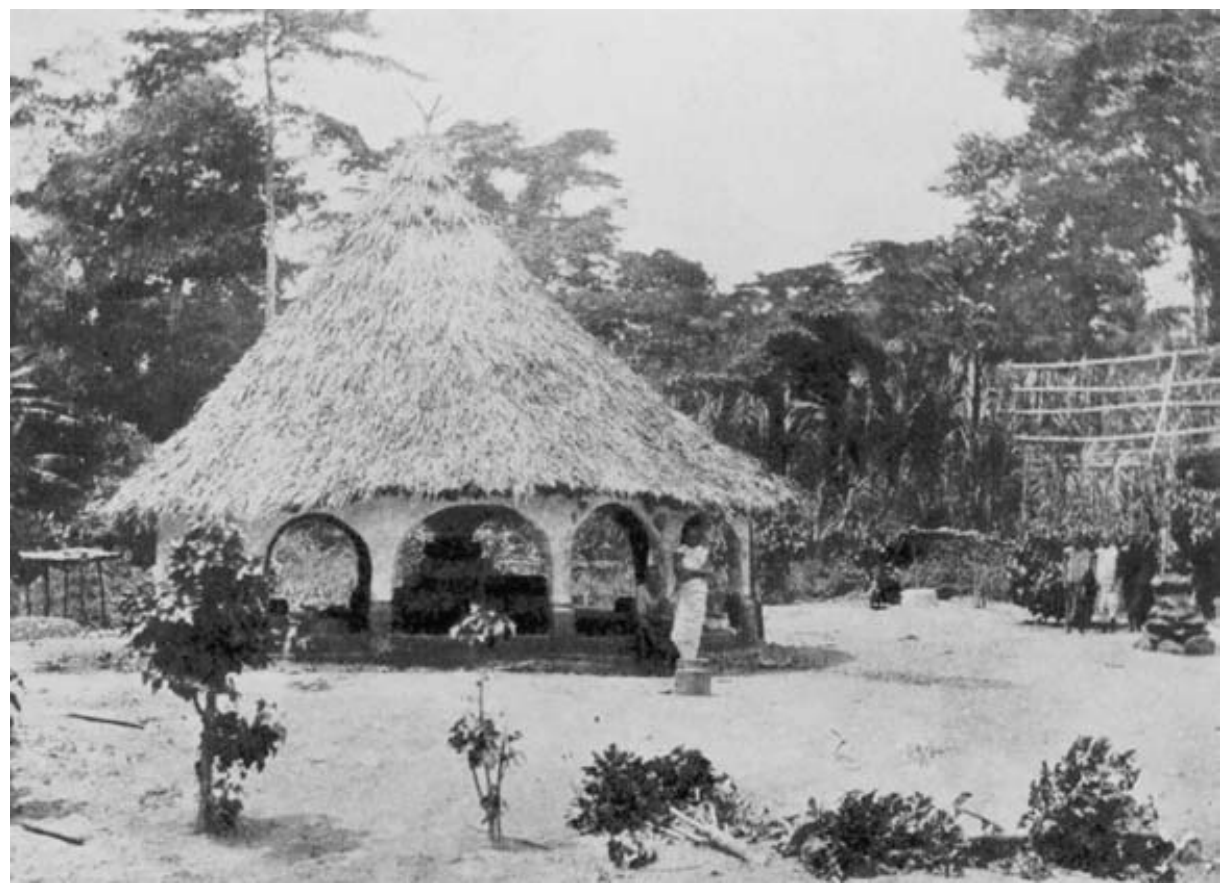

Fig. 2. Arthur Ffoulkes's original caption for this photograph reads: 'A good specimen of a Borgya shrine, showing the erection for skulls, on left and right, with the stone cairn, and part of the circular hedge cut down in the foreground. Tano-Dumase in Ashanti'. From Yournal of the African Society, 8 (1908-9), facing 388 .

manifestations of the twin deities varied. They most commonly took the form of balls of compressed organic matter, decorated with cowries in the case of Manguro/Burogya and invariably described as black in the case of Aberewa. In some locations they were represented by a pair of anthropomorphic figures fashioned from wood or clay. At one shrine in the western Gold Coast investigated by Ffoulkes, the suman was even embodied by a living tortoise ('which I at once rescued and have kept alive as a trophy'). ${ }^{62}$ According to information compiled by agents of the Basel Mission, once messengers had been sent to Takyiman or direct to Bonduku requesting Aberewa, the 'high priest' Osei Kwaku himself or one of his deputies would convey the sacred objects and associated ritual paraphernalia in pomp from the northwest.

His retinue consists of a body-guard of slaves, a company of drum-beaters, a number of speakers (whose duty is to explain his oracular thoughts and mystic movements) [i.e. akyeame], and a band of singers and dancing men (Ogurufo), each containing a bottle-shaped calabash containing pebbles, which he shakes as he goes along dancing and shouting ... As the procession nears a village ... the dancing men, exerting themselves to the utmost, dance, shout, gesticulate wildly, shake their 'rattles', crying out continually 'Hu ni! Hu ni! Aberewa na oresen no,

${ }^{62}$ Ffoulkes, 'Borgya and Abirwa', 39 I. 


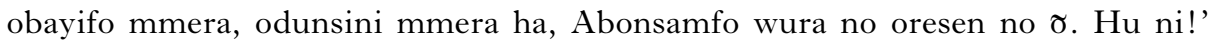
which means: 'Attention! Attention! Aberewa is passing. Witches, come forth. Sorcerers, come forth. The master of the devils is passing. Attention!'63

Much of this ceremonial can be interpreted as a conscious marketing ploy directed at emphasizing Aberewa's origin as an exotic Sarem power. In common with subsequent cults, this identity was underscored by the mimetic assemblage of a variety of generically 'northern' accoutrements. These included the prominent use in its rituals of the kola nut (a commodity actually harvested from the Akan forest but popularly associated with savanna culture), the use of divining rods to communicate with the god, the wearing of Gonja- and Mossi-style smocks by its officiating priests and-in what may be a faint echo of Islamic influence - the designation of Friday as its sacred day. ${ }^{64}$

The use of the sobriquet Abonsamfo wura also goes to the heart of Aberewa's ambiguous ritual identity. Translated by the missionaries Bauer and Ellenberger as 'master of the devils' but more correctly as 'master of the witches' (abonsam: a male witch or sorcerer, as opposed to a female sbayifo), Abonsamfo wura also captures the ambivalent nature of savanna witchfinders. That is, to defeat the terrifying anti-social power of bayi required asuman that originated from beyond the realm of human society and were to some degree of that very power. This ambivalence was further reflected in repeated rumours linking Aberewa to the appearance of snakes - the creature most intimately associated with bayi ${ }^{65}$ In this respect, a thread of continuity can be detected from Domankama in I879-80. That cult drew its ritual power from the sasabonsam, the ferocious child-devouring monster of the deep forest that was also perceived to be aligned with the forces of bayi ${ }^{66} \mathrm{But}$ mobilizing protective powers that were themselves associated with bayi was a highly risky business - on a number of levels. The Faustian dangers to body and soul are obvious. Moreover, as the practitioners of Domankama and of twentieth-century movements discovered to their cost, it could result in charges of practising bayi rather than fighting it, leaving them exposed to the

63 Bauer and Ellenberger, 'Aberewa', i6 I ; see also PRO CO 96/47 I, 'Account of the "Abirewa" fetish', 29 June I908; and RAG ARG I/30/I/6, Chief Kwaku Dua and Kwamin Assamuah to CCA, 3 Aug. I908. On the presence of 'slaves', note that while slavery had been effectively outlawed in the Gold Coast Colony in I 875, it remained legal in Ashanti until r 908 .

64 On the 'modernization' of the costume of Sakrabundi priests in French Gyaman from plant fibres ('tunique de feuilles') - as described by Freeman - to a white boubou, pants and bonnet ornamented with cowries, see Tauxier, Le noir de Bondoukou, i 84 .

65 See RAG ARG I/30/I/6, 'Some details about fitish Aberewa', by Ben Ampofo; PRO CO 96/47 I, C. N. Curling to secretary for native affairs, dd. Kyebi, I July i 908 . It is significant that bas-relief sculptures of coiled pythons were prominent in Sakrabundi shrines in Gyaman: see Delafosse, Les frontières, I 2 I ; Monnier, France noire, photograph facing I 56. This further suggests a link to Senufo traditions, where identical representations of the sacred python, fo, decorated the shrines of the Sandogo association, the women's parallel to Poro: see Herbert M. Cole, 'The Western Sudan', in Vinsonà et al. (eds.), Art in Africa, I 47.

66 R. S. Rattray, Religion and Art in Ashanti (Oxford, 1927), 29, citing an interview conducted in 1922 with Yaw Adawua, a famous 'witch-finder' and ex-adept of Domankama. 


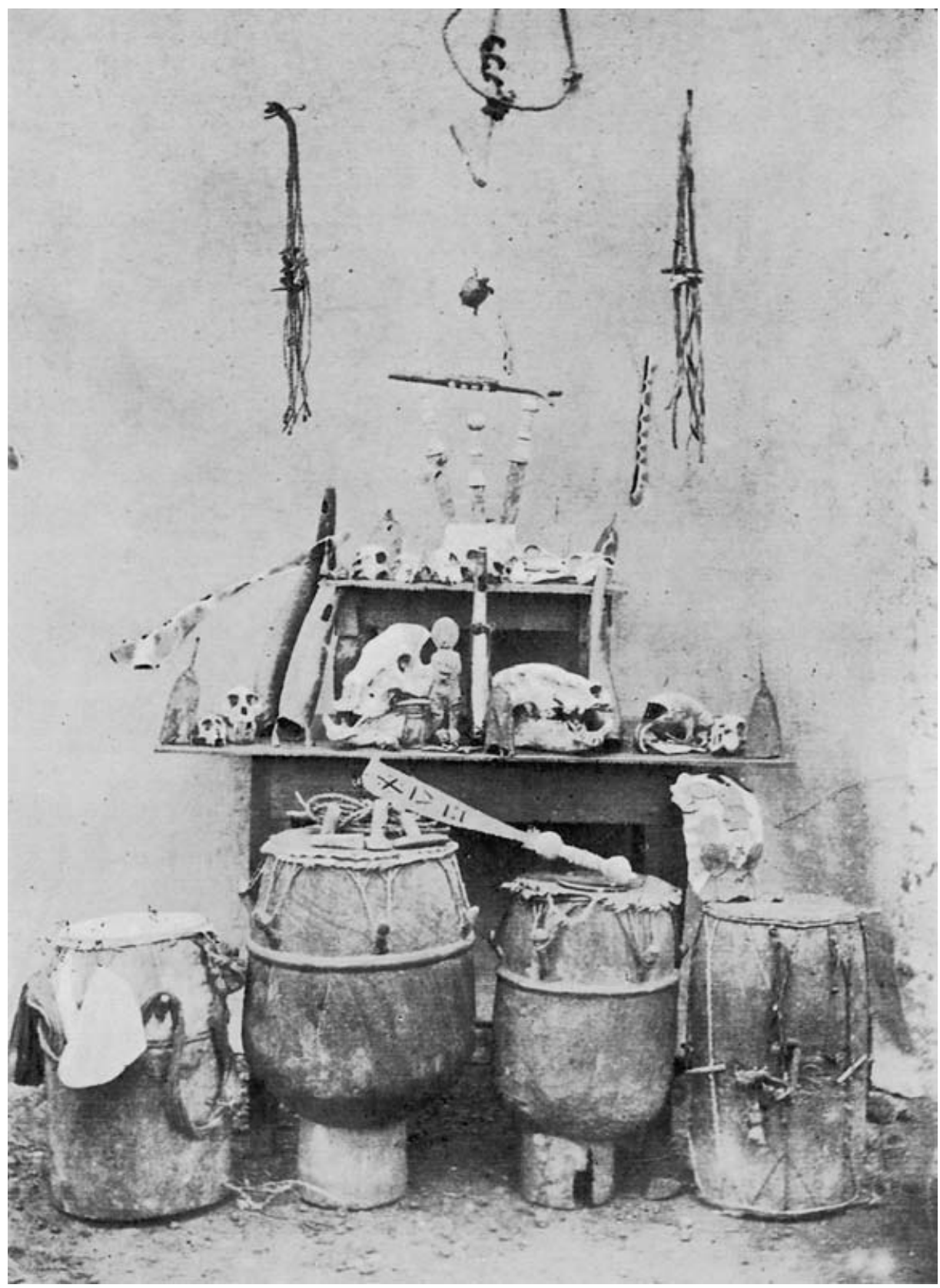

Fig. 3. The interior of an Aberewa shrine photographed by Ffoulkes in i 9o8. The ritual paraphernalia assembled includes the yago or forked divining stick balanced on two knives (top center), suspended above that a small turtle and to either side ahunum, knotted cords used to divine wrong-doing. Fournal of the African Society, 8 (1908-9), facing 396. 
intervention of a hostile state. The boundary between witch-finding and witchcraft, in other words, was far from clear.

As Aberewa began to capture the public imagination, British officials were at first not inclined to regard it as a threat to colonial control. On the contrary, Chief Commissioner of Ashanti F. C. Fuller was suitably impressed with the movement's injunctions against criminality and bad behaviour - in particular the rule that adherents should obey the new government. Following an enquiry in August 1907 prompted by alarmist reports from the Basel Mission of subversive new 'heathenish' customs, Fuller concluded that 'Aberewa worship will work for law and order', citing the 'metamorphosis it has caused in the Ejisu [Edweso] Country - formerly a hotbed of intrigue between people and chiefs and now a peaceful and united community' ${ }^{67}$ For the arriviste usurper Yaw Awua, the strategy of championing the new deity appears to have paid political dividends. Fuller went so far as to dismiss missionary warnings as a cynical attempt to 'counteract the proselytising success of the "Abirewa" propaganda' in the face of their own striking lack of Asante converts. ${ }^{68}$

The following year, however, official opinion began to shift, as leading chiefs in Asante and the Gold Coast Colony began to express unease at the increasing autonomy of the movement. Many began to fear that it would undermine hallowed indigenous abosom and their own authority. It is notable that in Asante the most strident complaints came from British-appointed chiefs who, unlike Yaw Awua, had failed to secure control over Aberewa. 'If you do not stop these people now ... the whole people would rebel against their chiefs', warned Atipinhene Kwaku Dua. '[B]ecause of this Fetish they talk once [i.e. as one]: even at present in every village they appoint a fetish man as chief.' ${ }^{\prime 69}$ Again, Reverend Asare provides key insights into Aberewa's emerging threat to established chiefly authority. 'The fetish is so much respected that some even call it a king', he observed. 'When the priest is talking to the people in the name of the fetish, he uses the expression "ohene $s e$ " (the king says)' ${ }^{70}$ Of those written petitions addressed to Fuller, it is notable that the only one advising him not to intervene against Aberewa was from Akua Afriyie, the daughter of the exiled queen mother Yaa Kyaa and one of the leading representatives of the 'legitimate' pre-I 896 regime of Asantehene Agyeman Prempeh. ${ }^{71}$

Much was made by Aberewa's opponents of the practice of mutilating the corpse of those believed to have been 'executed' for practising bayi or breaking one of the god's other injunctions. There were also reports that many of these victims were wealthy individuals deliberately targeted by the cult's local practitioners, who claimed the right to appropriate a portion of the movable property of the deceased. 'Aberewa e! Wukum a kum nea srade wom', the performers were said to sing at the god's weekly, often all-night, ceremonies taking place on the edges of towns and villages across the forest

67 PRO CO 96/47 I, Fuller to colonial secretary, 8 Aug. I907. $\quad{ }^{68}$ Ibid.

69 RAG ARG I/30/ı/6, Chief Kwaku Dua and Kwamin Assamuah to CCA, 3 Aug. I 908; also Nkawiehene Kwabena Kufuor to CCA, 6 Aug. I 908.

70 BMA D-i,88/i 5, Annual Report ... for I 907.

71 RAG ARG I/30/I/6, Akua Afriyie to CCA, 3 I July i 908. 
zone: 'Aberewa, listen! If you kill, then kill one who is fat (i.e. rich)' ${ }^{72}$ According to a variety of negotiated arrangements, the property of the deceased was then divided up between their family, those who had established themselves as Aberewa 'priests' and local office-holders. A proportion was also sent back as tribute to Osei Kwaku in Côte d'Ivoire. The advancing cash nexus may well have been creating a raft of new anxieties that were expressed in the idiom of bayi. But the monetization of the local economy was also facilitating the circulation of ritual commodities. Fell noted that when Sakrabundi/Aberewa first appeared in what would become British Gyaman in the I 890 s, 'the price of Ju-ju was only a few cowries' but by I 908 it had risen to eight pounds. ${ }^{73}$ As reports indicated that many regions in Asante were sending hundreds of pounds worth of payments and gifts to Bonduku, British officials became increasingly concerned about the drainage of wealth across the colonial frontier.

The relationship between Aberewa and money raises a number of complex issues. If wealthy individuals were indeed targeted by accusations of bayi-and despite the obvious bias in the sources, this appears to have been the case in at least some instances - was it simply the result of unscrupulous ritual entrepreneurs manipulating the popular dread of witches as a mechanism of accumulation? Alternatively, were so-called 'bigmen' identified as abayifor because their wealth was understood to have been illegitimate, accumulated at the expense of the community? Similar questions have emerged in much of the recent anthropological research into the 'modernity' of witchcraft in contemporary Africa. The tendency in this literature is to answer the second question in the affirmative; to argue, in other words, that the idiom of witchcraft provides the most fluent means by which many Africans perceive and articulate the uneven accumulation of wealth and power. With regard to Aberewa, it must be emphasized that to make the same assumption does violence to the entire corpus of literature on the meanings of wealth and accumulation in Akan culture. In short, the emergence of the Akan forest kingdoms in their historic form was from the outset intimately bound up with the large-scale accumulation of wealth on the part of aggressively acquisitive gold-mining and agricultural entrepreneurs. Far from being perceived as anti-social, such wealth was celebrated. ${ }^{74}$ It is the case that excessive or punitive taxation by the state could be perceived as illegitimate-indeed, there is evidence that such actions by Asantehene Mensa Bonsu may have acted as a catalyst for the rise of Domankama in I $879 .{ }^{75}$ But there is no indication that this fundamentally positive view of individual accumulation shifted with the widening of economic opportunities under the new colonial dispensation. A close reading of the archival record of twentieth-century witch-finding movements suggests that both unconscious bayi and the deliberate use of aduto were more often than not seen to be directed by the 'have-nots' towards the 'haves' rather than the

72 Bauer and Ellenberger, 'Aberewa', i 62.

73 RAG ARG i/30/r/6, Fell to CCA, dd. Sunyani, 3 Sept. i 908.

74 The literature is voluminous, but see esp. Wilks, Forests of Gold, I27-67; T. C. McCaskie, 'Accumulation, wealth and belief in Asante history. I. To the close of the nineteenth century', Africa, 53 ( I 983), 23-44, and 'II. The twentieth century', Africa, 56 ( I 986), 3-23.

75 McCaskie, 'Anti-witchcraft cults', I 29-33. 
other way around. The word in English that emerges most commonly from the sources as a synonym of bayi is 'envy'. I would argue that the dynamics of Akan witchcraft and anti-witchcraft in the early twentieth century were too complex and nuanced to be reduced to the notion of a zero-sum moral economy. ${ }^{76}$

The social landscape of witchcraft accusation and confession in Asante and the Gold Coast was shaped as much by gender as by wealth. Despite the lack of statistical evidence, it is clear that the majority of individuals identified by Aberewa as abayifos were women. There can be little doubt that countless 'innocent' women were forced to submit to humiliating (and often sexually degrading) public rituals in the cause of a ruthless moral regeneration of the wider community. Yet many others came forward willingly to rid themselves of the affliction of bayi. Perhaps the best way of giving some indication of the wide spectrum of popular response is to look at one discreet episode. The location is the village of Mehama in the Bron kingdom of Ahafo in the far west of Asante, where in August 1908 Commissioner Fell investigated reports of brutality associated with Aberewa. ${ }^{77}$ Adwowaa Appia reported to Fell that she was charged $f^{2}$. I I when her daughter Akua Sinia was falsely identified as an sbayifo by local Aberewa 'fetishman' Yaw Kuntaw. 'As they were playing [i.e. ritually performing] I stood watching', Akua testified.

They came with a stick and pointed me a witch. They said when I admitted it I would be beaten. They forced me to admit it. I was afraid. I am not a witch. They took my properties - cloths and beads. They said I had killed by witchcraft ... I was compelled to say I killed 8 children ... Yao Chintor stripped me stark naked. They all hooted me in the street ... They put me down and dragged me through the street by the foot and put peppers on my privates. ${ }^{78}$

In contrast, other women embraced the movement eagerly. 'I am a witch', claimed Benyama, a slave from the north. "I brought the "witch" from my country. The Fetish caught me. I inherited witchcraft from my mother ... I wasn't badly treated. I washed the witchcraft off. I used to imagine to eat children'. ${ }^{79}$ Amma Bako from the neighbouring settlement of Diadiasuaba told a similar story: ' I was a witch and the Fetish got me ... I used to move at night. I imagined I eat [sic] children. The Fetish man gave me medicine. The witch came out. I am no longer a witch'. ${ }^{80}$ There is every indication, as McCaskie convincingly argues, that a dread of bayi was deeply rooted in Akan historical experience. ${ }^{81}$ But sources also indicate that within the framework of that fundamental belief, individual responses to eradication movements such as Aberewa ran from outright scepticism through empirical experimentation and on to ecstatic embrace.

76 Cf. Ralph A. Austen, 'The moral economy of witchcraft: an essay in comparative history', in Comaroff and Comaroff (eds.), Modernity and its Malcontents, 89-1 I.

77 RAG ARG I/30/I/8 Mehama Bungulu [i.e. Manguro] Fetish Case.

78 Ibid., 'Mehama Bungulu Case', by T. E. Fell, 30 Aug. I 908. 'The stick' with which Akua was pointed out is a reference to the so-called yago, the savanna-style divining rod through which Aberewa spoke and identified abayifos: on its use, see Ffoulkes, 'Borgya and Abirwa', 39I-2.

79 RAG ARG I/30/I/8, Notes of Evidence, 3 Sept. I 908.

80 Ibid., 'Enquiry into brutality connected with "Bungulu”' fetishes', 3 Sept. I909.

81 McCaskie, 'Anti-witchcraft cults', I 29. 
In August I 908, Chief Commissioner Fuller finally decided to act. In the face of what he described as 'a sudden eruption of Abirewa fanaticism, in the shape of ill-treatment of corpses, subversion of Chiefly powers and wholesale collections for the benefit of the "Pontifix Maximus" of the cult', he reversed his previous policy of tolerance to one of suppression. ${ }^{82}$ On 6 August, without waiting for legal confirmation from the colonial headquarters in Accra, he announced the prohibition of Aberewa in Ashanti to a large and reportedly tense gathering outside the fort in Kumase. In an extraordinary address Fuller openly taunted the Asantes for being taken for a ride by northern peoples who were once their subjects and slaves, repeating rumours that the Gyamans "clap their hands and say "By these tricks of Fetishes we are getting back from Ashanti all the moneys and tributes they took from us in the old days"' '.83 Fuller pressed home his point by highlighting the role of 'the redoubtable' Yaw Nokwobo, the 'ex-Grunshi slave in Ashanti and Chief Emissary General from the High Priest', who had earlier been taken into custody:

I have here now, behind me, one of the leading men in this Religion. He happens to be, or used to be, an Ashanti slave. Now he is becoming a very big man. He has got a lot of money out of it, and hopes to get more. What does a slave like better than to turn on his former master ? $^{84}$

Speaking only a few months after the abolition of the legal status of slavery in Ashanti, Fuller clearly sought to touch a raw nerve with his audience. He may have done even more than that, as his taunts inadvertently went to the very heart of the tension in Akan perceptions between the 'primitive' Gurunsi nnonksfos and ritual power. The most pronounced official fear, however - and it was one that would recur throughout the ensuing history of anti-witchcraft movements in the colonial Gold Coast - was that Aberewa represented an alien and therefore illegitimate religious form that was fundamentally subversive of 'traditional' tribal authority. 'The Ashantis have always had gods of their own; they have always worshipped their ancestors', Fuller insisted. 'What have your ancestors done that you should stop worshipping them?' ${ }^{85} \mathrm{Or}$, as a report on a suspected resurgence of Aberewa stated four years later:

The real danger that I see in them - I speak of the extra-tribal as distinct from the tribal or ancestral fetish - is their tendency to set aside tribal authority. Their service exacts a freemasonry that is ... subversive of good order. ${ }^{86}$

In the Gold Coast Colony, the lead was taken by African authorities rather than the colonial state. By mid-r9o8, the amanhene of Akyem Abuakwa, Akuapem and New Dwaben had all declared Aberewa to be subversive of their authority and therefore prohibited. But without coercive power their intervention had little impact. In the corridor from Kwawu south through the heart of the expanding cocoa country of the eastern Gold Coast, Aberewa

${ }^{82}$ PRO CO 96/47I, Fuller to colonial secretary, I 5 Aug. I 908.

${ }^{83}$ Ibid., 'Meeting held on the 6th August 1908 outside the fort at Coomassie'.

${ }^{84}$ Ibid. ${ }^{85}$ Ibid.

${ }^{86}$ RAG ARG I/30/7 Abirewa fetish 1907-12, minute by F. Crowther, secretary for native affairs, 6 July i9I 2 . 
continued to flourish 'in almost every town'. ${ }^{87}$ After pleas from the worried amanhene, the movement was formally banned in the Colony by the Executive Council under Section I 4 of the Native Customs Ordinance of I 892 on I7 July I908. The ordinance was extended to the separate legal jurisdiction of Ashanti the following month. Like Domankama three decades before, Aberewa had incurred the hostility of an authoritarian state that was suspicious of its engagement with the supernatural and fearful of its ability to mobilize followers outside established structures of belief. Throughout the second half of I 908 , the paired shrines on the kurotia of villages throughout Asante and the Gold Coast were systematically demolished by the colonial police. 'The order was implicitly obeyed throughout the country', Fuller would later conclude, 'and in no single instance was coercion necessary'. ${ }^{88}$

\section{AFTERMATH AND CONCLUSIONS}

By i9ıo, Aberewa had ceased to operate as a large-scale, public phenomenon. The threat to law and order and established custom appeared to have been seen off by a coalition of indigenous office-holders and the colonial state. The Christian missions were also relieved to see the demise of what they regarded as a most pernicious form of 'fetishism'. This was particularly the case in Asante, where Basel missionaries identified the defeat of Aberewa as the key breakthrough in their struggling evangelical project. ${ }^{89}$ Yet the state could not legislate against the popular perception that bayi was abroad in the land. 'Many villages asked me to substitute a protection against witches and evildoers', T.E. Fell reported as he made his way through the western marches of Asante gathering up ritual paraphernalia, 'and ... I fear we must take a belief in witchcraft for granted'. ${ }^{\mathbf{9}}$

That belief ensured that flows of ritual commodities and knowledge across porous cultural, ecological and political frontiers would continue. As early as I9 12, a delegation from Wankyi was said to be back in Bonduku shopping for a new stock of 'grand fétiches' to replace those incinerated by British officials. ${ }^{91}$ In that year too, public witch-finding began to re-emerge in the Gold Coast, although colonial officials and hostile chiefs were uncertain whether they were dealing with Aberewa in a new guise or with distinct - and therefore legal - gods. The illusive, protean nature of anti-witchcraft movements meant that this uncertainty was often shared by their own acolytes. It also explains in part why the colonial suppression campaign of 1908 met with

${ }^{87}$ Ibid., C. N. Curling, commissioner of the Eastern Province, to secretary for native affairs, I July i 908.

${ }^{88}$ Francis Fuller, $A$ Vanished Dynasty: Ashanti (London, I92 I), 222; on the destruction of shrines in Asante, see The Gold Coast Leader, 29 Aug. I 908. It may be noted, however, that District Commissioner Arthur Ffoulkes, who co-ordinated the destruction of Aberewa in what had become a stronghold of the movement in the western Gold Coast kingdom of Sehwi, did not survive the operation. He died of blackwater fever in January I 909 (see ibid., 6 Mar. I909). Local reactions to this event appear to be unrecorded, but it is inconceivable that his demise would not have been attributed by followers of the movement to Aberewa.

89 BMA D-1,90/74, Annual Report of Kumase Congregation, by N. V. Asare, 22 Feb. I909. ${ }_{90}$ RAG ARG I/30/1/6, Fell to CCA, dd. Sunyani, 3 Sept. I 908.

91 Tauxier, Le noir de Bondoukou, 194. 
so little overt resistance. The order to abandon Aberewa may have been 'implicitly obeyed', but the growing availability of exotic ritual resources ensured that ritual armouries could be replenished by new northern witchfinders. For the remainder of the colonial period and beyond, the ebb and flow of Aberewa, Kunde, Senyakupo, Nana Tongo, Tigare and other savanna gods was characterized by polymorphous transformation, local adaptation and deliberate disguise. In the I980s, a century after Freeman witnessed the swirling dances of Sakrabundi acolytes in Odumase, anthropologist Judy Rosenthal identified 'Nana Ablewa' and 'Sacra Bode' as two of the savanna spirits of the Gorovudu possession orders amongst the Ewe and Guin peoples of coastal Togo far to the southeast. ${ }^{92}$ Traces of the god's epic passage from the northern grasslands through the Akan forest and on to the Atlantic seaboard can also be found in the Fante coastal towns of Ghana. In Elmina and elsewhere, Sakrabundi lived on into the late twentieth century - not as a ferocious witch-finder, but as a stock carnival character whose ritual power remained only a vague memory. As the towering 'Stilt Dancer', Sakrabundi joined annual parades of papier-mâché-masked figures drawn from the liminal zones of human experience such as 'Ghost', 'Fetish Priest', 'Ship Captain', 'Odonsu' (a multi-headed river spirit) and 'Sasabonsam'. ${ }^{93}$

Ritual innovation also continued back in the Cercle de Bondoukou, where in the I 920 S French officials and missionaries launched a belated assault on Sakrabundi. The great masks admired by Freeman in I 889 were hunted down and burnt and Osei Kwaku's shrine complex at Wirekye destroyed. In about I930, however, Sakrabundi was discreetly 'brought out' once again in a new guise, called Bedu. According to Bravmann, 'Bedu employed masks but dealt with " positive" issues - human fertility, prevention of epidemics, and internal social control - and was thus apparently tolerable to the colonial administrators'. ${ }^{94}$ Meanwhile, the old god Sakrabundi (or Sakara-Bounou), shorn of its spectacular public rites and regalia, continued to deal behind the scenes with the continuing social problem of witchcraft. By the late r940s, Sakrabundi/Aberewa had also been revived across the border in Wankyi, where Meyerowitz witnessed a nocturnal ritual performance strikingly similar to that first recorded by Freeman. ${ }^{95}$

Three main conclusions can be drawn from this study of Sakrabundi and its ritual offspring Aberewa. The first concerns the timing of their appearance in the Akan region, in particular the question of the impact of colonial conquest on indigenous perceptions of witchcraft and anti-witchcraft. The rise of Sakrabundi as the predominant anti-witchcraft cult or 'power association' in Gyaman in the late nineteenth century and its diffusion at least as far south as the Tano River by 1889 shows that the waves of heterodox religious movements that swept through the Gold Coast in the first half of the twentieth century were in part based on older flows of ritual products and knowledge from distant savanna shrines to the Akan forest. Yet the coming of colonial rule not only facilitated the commoditization and mobility of

92 Rosenthal, Possession, Ecstasy, and Law, 22.

93 Herbert Cole and Doran Ross, The Arts of Ghana (Los Angeles, I977), I 82-4; for indications that the Do masking association also reached the Fante towns of the coast, see Cole, 'Akan worlds', 220. 94 Bravmann, Islam and Tribal Art, 102-3.

95 Meyerowitz, The Akan of Ghana, I 24. 
exotic religious resources, it also created the conditions by which the demand for those resources reached new heights. Perceptions of and responses to anti-social bayi were therefore characterized neither by abrupt change (as argued by colonial-era ethnographers) nor an essential continuity (as countered by Goody), but by complex patterns of interaction between the two.

Second, the trajectory of the two movements suggests that the role of northern savanna peoples in the history of Asante and the other Akan kingdoms - and in the colonial entity that would become modern-day Ghana-requires significant re-evaluation. Despite Ben Ampofo's Akanized linguistic gloss on the name Sakrabu(n)di, the weight of evidence points to the movement having emerged from the nexus of ritual interaction between Mande communities on the one hand and the diverse Gur- and Senufospeaking peoples on the other in the grasslands to the northwest of the Akan world. Far from being perceived simply as a remote backwater beyond the realm of civilized order, the savanna was regarded by the Akan and their neighbours on the Gold Coast with a deep ambivalence. The so-called 'Gurunsi' and other non-centralized savanna-dwellers may have been derided as primitive rustics, but they were also seen to possess an array of the most potent ritual powers and the esoteric knowledge necessary to mobilize them in the battle against bayi. To borrow Wilks's formulation, the 'northern factor' in Akan history was not limited to the creative contribution of Muslim scholars and merchants alone. It extended to an expanding crosscultural ritual commerce at the centre of which were a range of savanna peoples who hitherto have been swept to the margins of Ghanaian history.

Finally, the reconstruction of the dynamics of Sakrabundi and Aberewa demonstrates the importance of thinking about witchcraft and anti-witchcraft as historical processes rather than as a set of either 'traditional' or 'modern' beliefs and practices. It is with regard to this conclusion in particular that the narrative of trans-regional ritual innovation across the savanna-forest frontier of Côte d'Ivoire and Ghana in the late nineteenth and early twentieth centuries speaks to the broader study of religion in Africa. It is now well recognized that indigenous belief systems in many parts of the continent demonstrated considerable resilience in the face of the twentiethcentury expansion of Islam and Christianity, while the spread of the world religions themselves was characterized by a high degree of localized adaptation and mutation. This article argues for the importance of the space between the local and the global, a space occupied by innovative ritual entrepreneurs such as the Abron 'fetish priest' Osei Kwaku and the 'exGrunshi slave' Yaw Nokwobo as well as by the tens of thousands of acolytes who embraced the protection of distant savanna gods in times of abrupt change. Like later generations of wandering revivalists, self-styled prophets and purveyors of exotic esoterica in Ghana as well as elsewhere in the continent, these figures and the ephemeral movements they generated emerge only vaguely from a fragmented historical record. But they carved out a role as the mediators of ritual solutions as modern as those offered by the evangelists of Islam and Christianity. 